\title{
Lack of Compressional Overprint on the Extensional Structure in Offshore Tainan and the Tectonic Implications
}

\author{
Allen T. Chen ${ }^{1}$ and Yu-Liang Yang ${ }^{2}$
}

(Manuscript received 21 November 1995, in final form 15 November 1996)

\begin{abstract}
The nature of the plate boundary between the Eurasian and Philippine Sea Plates changes from subduction to collision along the northern extension of the Manila Trench, north of $21^{\circ} \mathrm{N}$, offshore southwest Taiwan. To determine whether the collision-formed deformation front passes through the Tainan Basin, a region of petroleum interest, seismic profiles that cross a proposed "deformation front" are interpreted. However, only a major normal fault, that is a growth fault that forms the northwestern side of a tilted horst structure can be positively identified. The nature of this normal faulting is also supported by the modeling of gravity and magnetic data.

The observation of only tensional faults in the Tainan Basin suggests that the deformation front is located to the southeast, near Kaohsiung or even further to the south.

The economic basement in the Tainan Basin region, defined as preTertiary rocks that underlie the thick Tertiary sequences along the seismic lines we examined, maintains a depth of 3 to $5 \mathrm{~km}$ in a tilted horst-like zone, known as the Central Uplift, and deepens in either direction away from it. The thick Tertiary deposits provide excellent potential for source rock and seal. Petroleum exploration in this area should be directed toward generating prospects related to normal faulting if structural closures can be identified.
\end{abstract}

(Key words: Deformation front, Tainan Basin, Seismic data)

\section{INTRODUCTION}

The Manila Trench is the tectonic boundary between the Eurasian and Philippine Seat Plates. The manner in which it extends north of $21^{\circ} \mathrm{N}$ has been the topic of much debate (e.g.. Bic. 1972; Karig, 1973; Bowin et al.. 1978; Lin and Tsai. 1981, Page and Suppe, 1981: Hayes and Lewis, 1984; Lundberg et al.. 1991; Chen and Ho. 1992). One of the most recent propositions regarding the northern extension of the trench is that it closely follows the trace als

\footnotetext{
${ }^{1}$ Institute of Applied Geophysics, National Taiwan Ocean University, Keelung, Taiwan, R.O.C.

2 Offshore and Overseas Petroleum Exploration Division of the Chinese Petroleum Corp. Taipei,

Taiwan, R.O.C.
} 
suggested by Letouzey and Sage (1988), such that the deformation front changes its direction from northwesterly to northeasterly near $22^{\circ} \mathrm{N}$ and passes through the Tainan Basin as the collision zone of the two plates (Figure 1) (e.g., Huang, 1993). Typical trench topography is not identifiable here because the nature of the plate boundary changes from subduction to arccontinent collision north of $21^{\circ} \mathrm{N}$ (Biq, 1973; Suppe, 1988; Teng, 1990). The deformation front produced by this collision can serve as an indicator to trace the tectonic boundary in the region offshore southwestern Taiwan. If the deformation front, such as the one proposed and shown in Figure 2 (e.g., Letouzey and Sage, 1988; Huang, 1993) does exist within the Tainan Basin, its geological implications must be different from those presented in some previous studies (e.g., Hu, 1988). Earlier geological works related to petroleum exploration generally have recognized that the Basin contains prevalent normal faults ( $\mathrm{Hu}, 1988)$ and inferred that it has been under tensional stress since it was formed in the Oligocene. If the collisional deformation front has indeed migrated into the Basin, it would imply that the thrust-fault systems could have seriously affected the way that prospects or closures of oil reservoirs have formed, and at the compressional stage in the history of the evelution and development of the Basin, they should, therefore, present a different scenario for prospect generation from that which is currently believed.

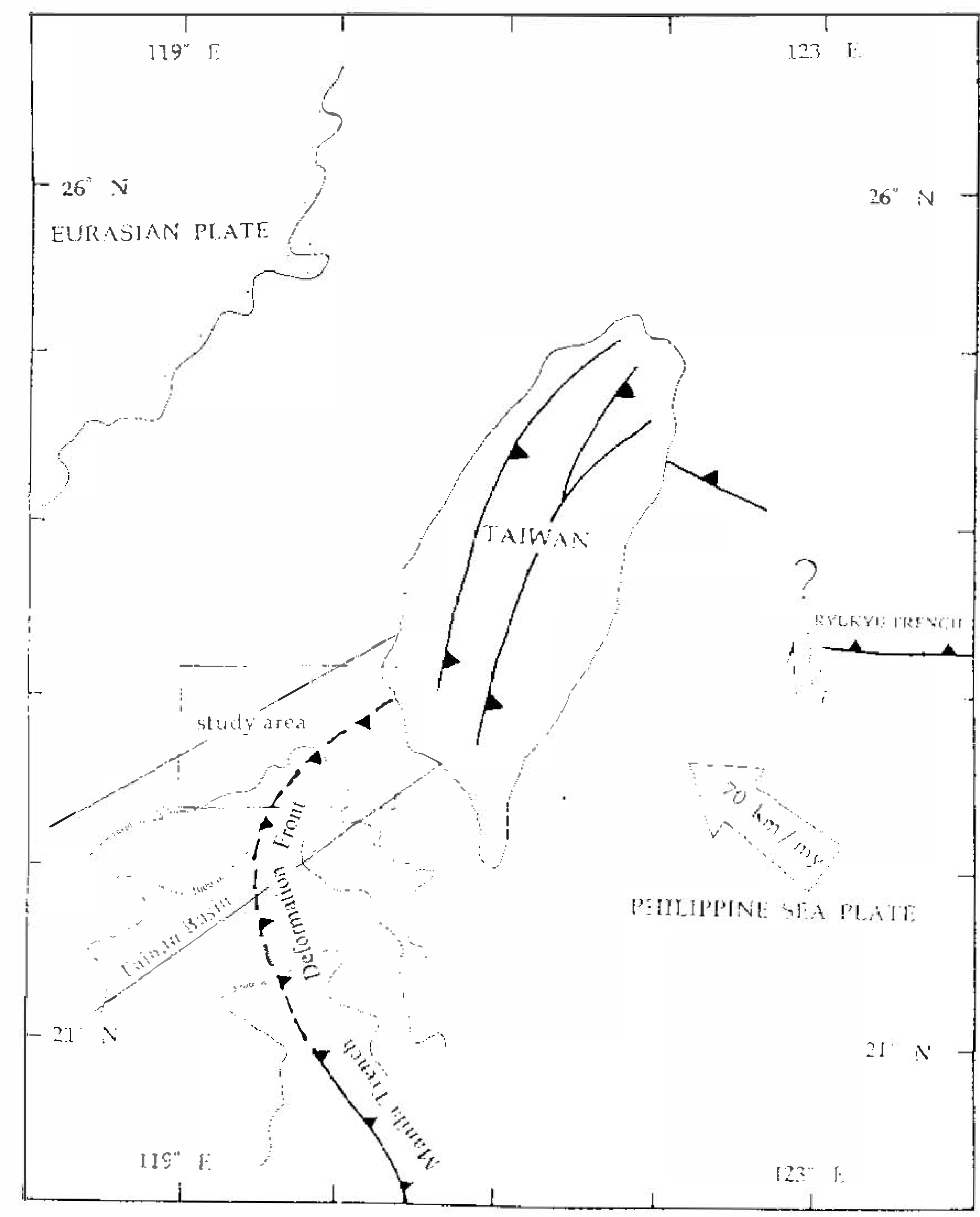

Fig. I. Regional map of Taiwan. It has been suggested that the collisional deformation front (after Huang, 1993) associated with the Manila Trench passes through the study area in the Tainan Basin which is roughly outlined ( $\mathrm{Hu}, 1988)$. 
To determine and evaluate the nature of the collisional deformation front in offshore Tainan, seismic profiles and potential-field data acquired in the Basin were analized and interpretations were made. The tectonic implications of the faulting related to the northern extension of the Manila Trench are also discussed in this paper.

\section{REGIONAL GEOLOGY AND TECTONICS}

The Tainan Basin is located in the northeastern corner of the South China Sea, in water depths shallower than 2000) meters (Figure 1). The formation of the Tainan Basin was related to the second stage of the seafloor spreading of the South China Sea Basin in the early Late Oligocene (Ho, 1982; Ru and Pigotte, 1986; Liang and Lin, 1990). A series of northeast trending normal faults produced the asymmetrical pattern of grabens and horsts due to a regional tilt, characterizes the structural style of the Tainan Basin. The Basin consists of three structural units: the North Recession, the Central Uplift and the South Recession (Figure 2) (Tsao and Chang, 1988). Although the Tainan Basin received abundant Tertiary sediments and deepened during the Miocene, such development and deepening was hindered and eventually terminated when the collision between the Philippine Sea Plate and the Eurasian Plate initiated in the Pliocene. In fact, the episode of collision, which has been one of the most important tectonic events in the region of Taiwan, resulted in the uplift of the islands.

The oldest strata recovered from wells drilled in the Tainan Basin have been dated as preOligocene (unpublished data from wells). Cretaceous rocks are dominated by nonmarine sandstones alternating with shales, and are overlain directly by Oligocene strata (Chuang et al., 1991). Based on magnetic data (Pan, 1968), total sedimentary thickness can reach more than

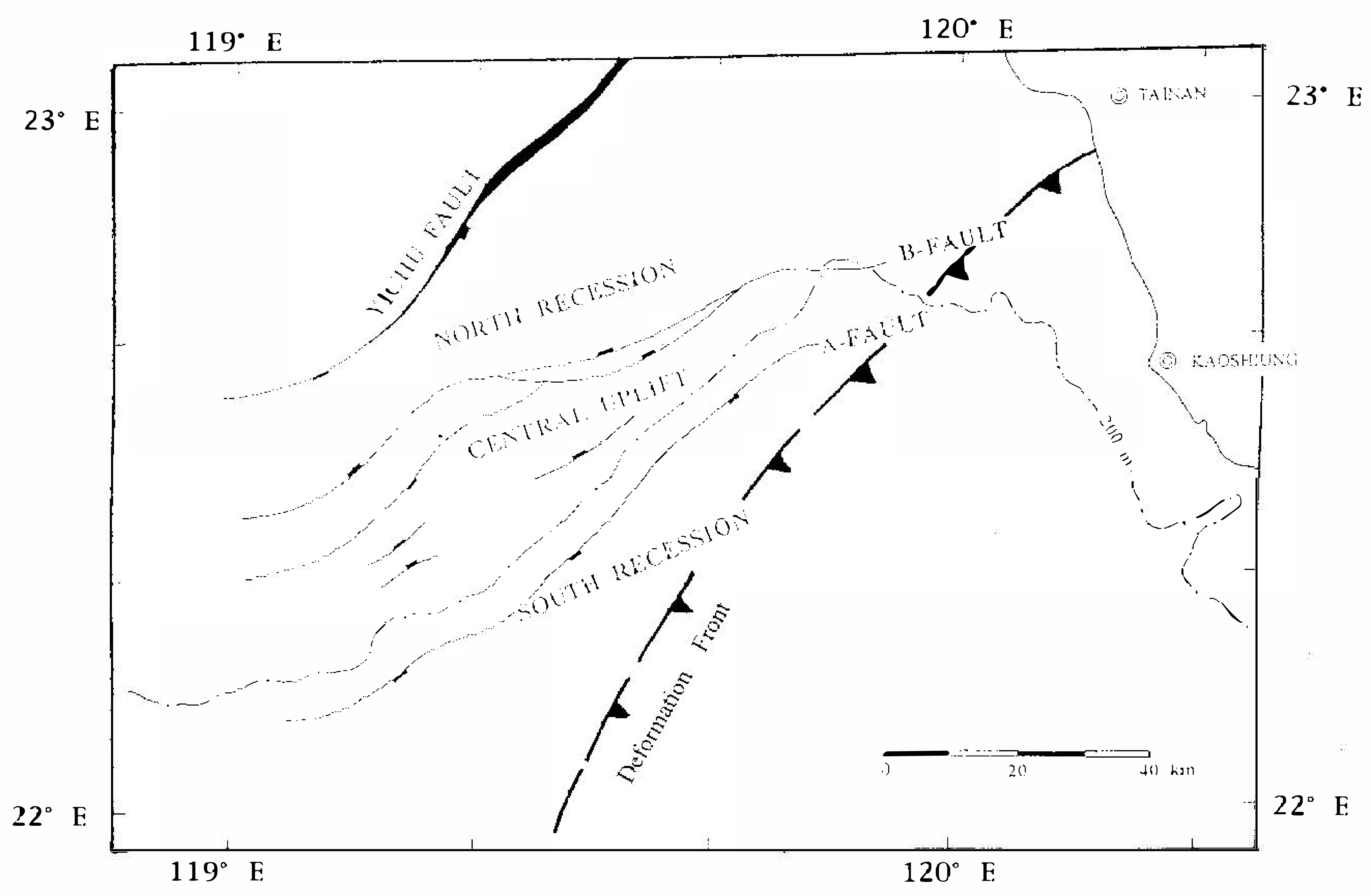

Fig. 2. Three structural units appear in the study area: North Recession, Central Uplift, and South Recession. The major faults shown include Yichu, A and B Faults, all related to the development of the Basin. (after Tsao and Chang, 1988) 
7000 to $8000 \mathrm{~m}$. The source of the sediments of the Basin has mainly been the Central Range of Taiwan starting in the Pliocene (Ho, 1982).

\section{DATA AND METHODS OF ANALYSES}

The seismic lines available in this study were acquired with a 2400-m streamer of 96 channel receivers maintained at a depth of $12 \mathrm{~m}$ below sea level. An air-gun array at a water depth of $5 \mathrm{~m}$ was shot every $25 \mathrm{~m}$. Line spacing of the survey ranged from 4 to $10 \mathrm{~km}$. The gravity and magnetic data simultaneously acquired in the seismic survey were used in forward and inverse modeling to confirm seismic interpretations. The seismic profiles were processed to 48-fold migrated sections at the facilities of the Chinese Petroleum Corporation.

Gravity data were first reduced to free-air gravity, from which residual and regional maps in turn were generated. The gravity residual was used to infer the shallower sedimentary structure which overlies the basement. The software package SAKI, developed by the United States of Geological Survey was adopted here to compute both the theoretical gravity and magnetic values on the basis of an initial model obtained from seismic interpretations. The density of the Cretaceous economic basement was assumed to be $2.67 \mathrm{gm} / \mathrm{cm}^{3}$, and each stratigraphic layer was assigned a value of density which was converted from the interval velocity following the formula $r=0.3095 \mathrm{~V}^{0.25}$, where $\mathrm{r}$ is density, and $\mathrm{V}$ is interval velocity ( Gardner et al., 1974).

If the difference between the observed and calculated values exceeded a pre-defined limit, modifications were made to either the density values or the model, and the computation was repeated until the difference fell within the pre-defined values. The inversion technique was also applied in order to further refine the model.

The magnetic data, on the other hand, were reduced to the residual anomalies after subtraction of the International Geomagnetic Reference Field (IGRF) and the removal of diurnal variations and regional trends from it. Diurnal variations were obtained from the records collected at Tseng Wen Station. The parameters adopted in the magnetic modeling included a total field intensity of $438\left(03.7\right.$, an inclination of $31.2^{\circ}$ and a declination of $-2.36^{\circ}$. The theoretical magnetic values were computed and compared with the observations. Because of the absence of actual measurements of magnetic susceptibilities, appropriate values from general publications (e.g., Telford et al., 1976) were adopted and assigned to sedimentary layers and the economic basement. If a significant mismatch was found, the susceptibility values or the model were modified and the modeling procedure was repeated until the difference between the theoretical and observational values fell within a pre-defined limit. The inversion technique was employed to obtain the final model used in this study.

Most seismic lines used in the interpretation of the structural and stratigraphic features in the study area cross the hypothesized collisional deformation fiont. The age of each seismic horizon was identified through correlation with nearby seismic profiles for which velocity and depth information are available from well logs along Lines 12 and 53 (Figures 3, 4 and Table 1). The odd-numbered parallel seismic lines, except for Line 27 , are roughly perpendicular to the trend of the proposed "deformation front" and are tied to even-numbered perpendicular lines. The traced horizons show varied acoustical character: from strong reflections with good continuity to poor reflections with discontinuity. The authors concentrate their interpretations near the structure of the "deformation front". 


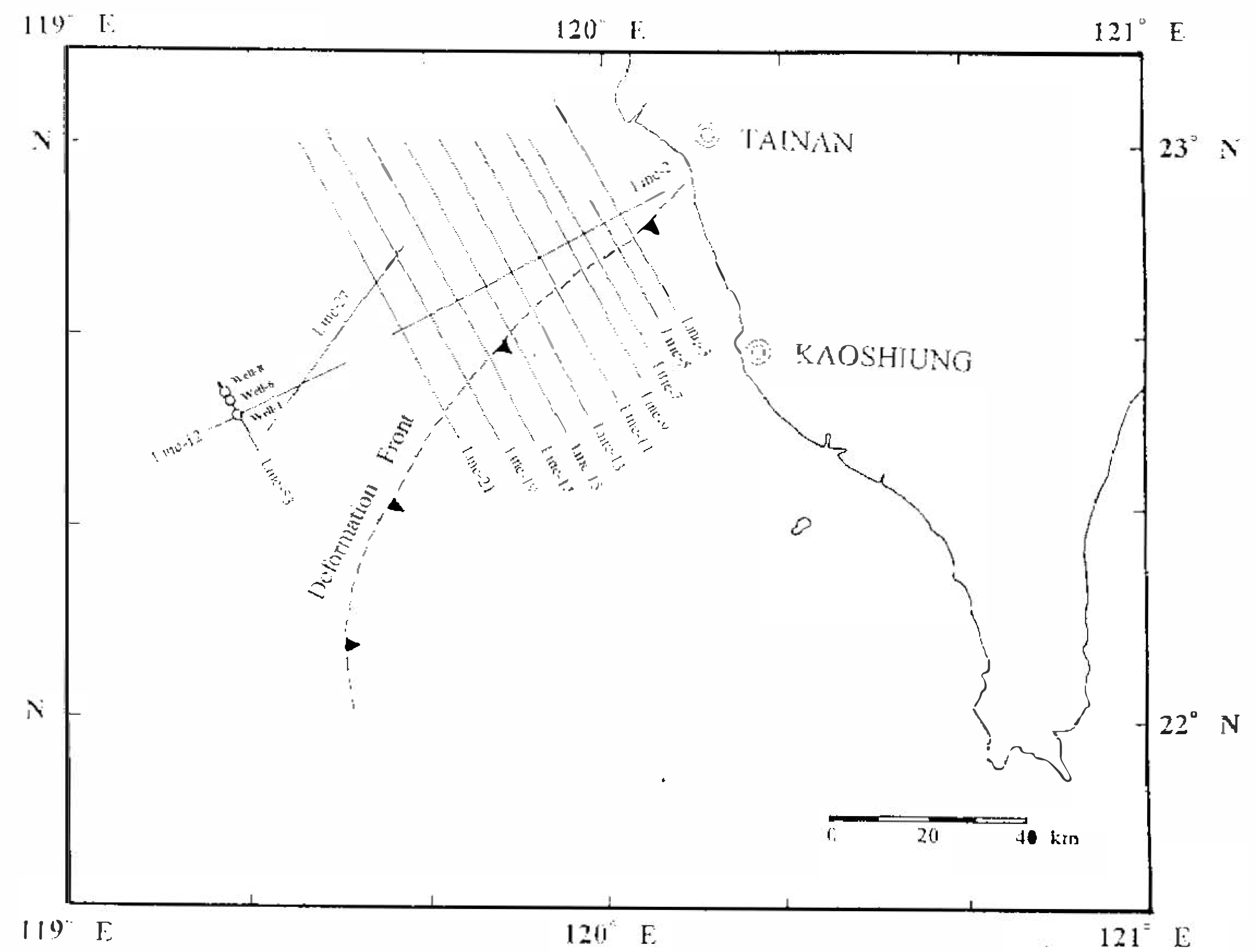

Fig. 3. Location map of seismic lines and wells in the study area. The projected trace of the deformation front is indicated by the barbed line.

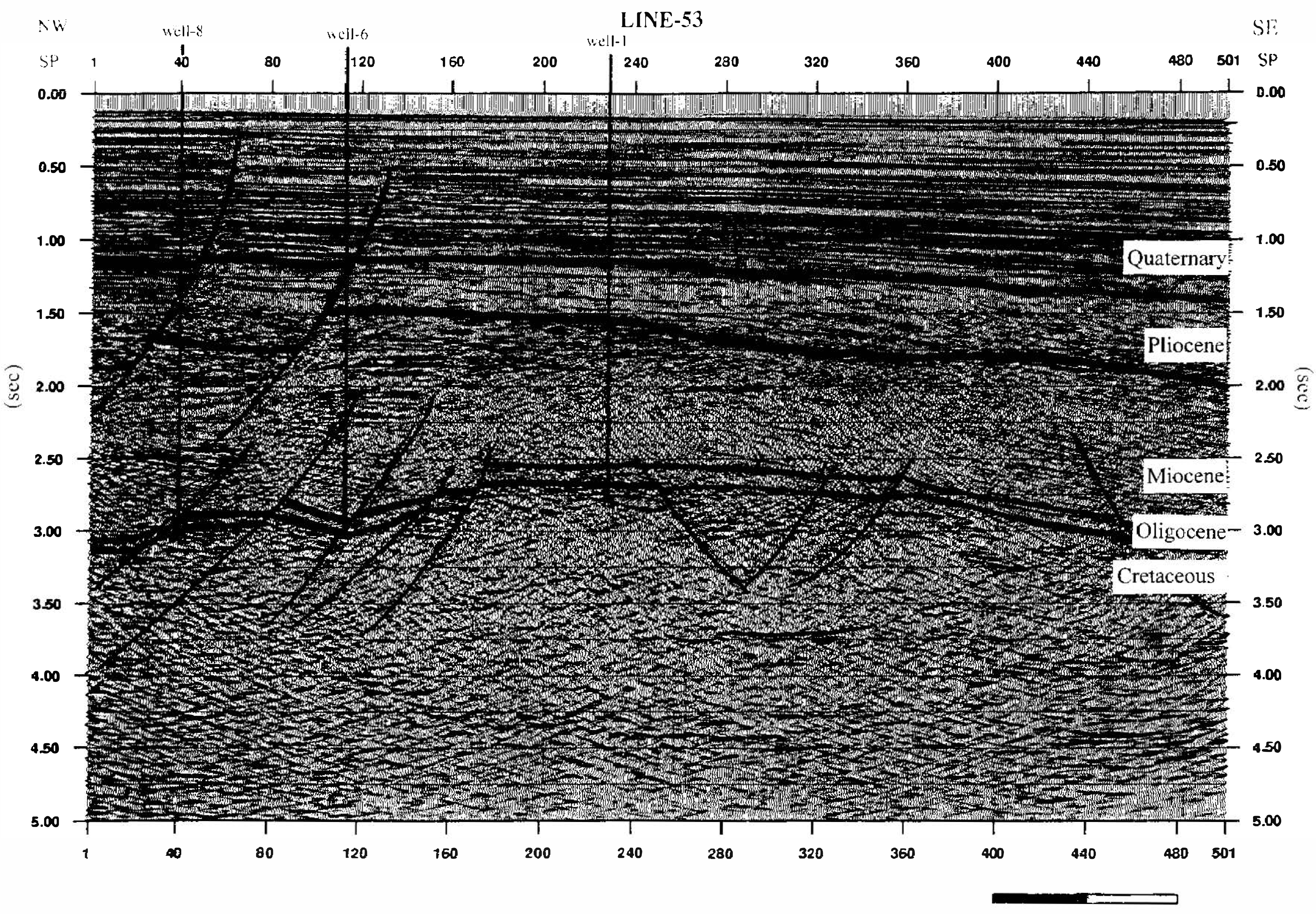

Fig.4. Seismic Line-53 with well locations indicated. 
Table 1. Stratigraphic boundaries based on sonic logs.

\begin{tabular}{cccc}
\hline \multicolumn{1}{c}{ Age } & Well-1 & Well-6 & Well-8 \\
Top of Pliocene (M.) & 1133 & 1175 & 1160 \\
(Sec.) & 1.11 & 1.13 & 1.14 \\
& & & \\
Top of Miocene & 1825 & 1890 & 1812 \\
& 1.66 & 1.69 & 1.66 \\
Top of Oligocene & 3117 & 3435 & 3595 \\
& 2.50 & 2.73 & 2.73 \\
Top of Cretaceous & 3241 & 4007 & 4024 \\
& 2.57 & 3.02 & 2.97 \\
Top of Jurassic & 3584 & & \\
\hline
\end{tabular}

\section{DATA INTERPRETATION}

The "deformation front" (Huang, 1993) along each seismic line was identified and examined in this study. A northwest dipping fault within $10 \mathrm{~km}$ to the southeast of B Fault extending upward to the top of the Pliocene is observed along the northern edge of the structural high of the Central Uplift along Line-3 (Figures 2, 3 and 5). A similar feature is observed along other profiles up to Line-15 westward (Figures 6-11). The discontinuity of the reflectors below the curved strong reflector (1.6-1.9 sec) between those strata of the Quaternary and Pliocene age suggests that the northwestern block subsides relative to the southeastern block well into the Quaternary. The seismic character of Quaternary sediments maintains a high continuity with medium to high amplitude. Generally, reflections deteriorate downward through the entire section. The strata of the hanging wall are thicker than those of the footwall, characterizing a growth normal fault.

A strong reflector can be observed on the top of the acoustic basement (deeper than about $5 \mathrm{~km}$ converted from rms velocity) and forms a dome structure beneath the unconformity at the top of the Cretaceous strata in the footwall from Line-3 to - 15. The uplift of the basement causing the downward movement of the northern block might have been related to the regional tilt dipping to the south. The tilted horst-like structure corresponds to the Central Uplift zone, and the northwest-dipping normal fault is the B Fault, separating the Northern Recession from the Central Uplift (Figure 2) (Tsao and Chang, 1988).

The strong reflection at the top of the acoustic basement deepens to $4.3 \mathrm{sec}$ or more along Line-5 (Figure 6), while the strong reflection at the unconformity between the Quaternary and 


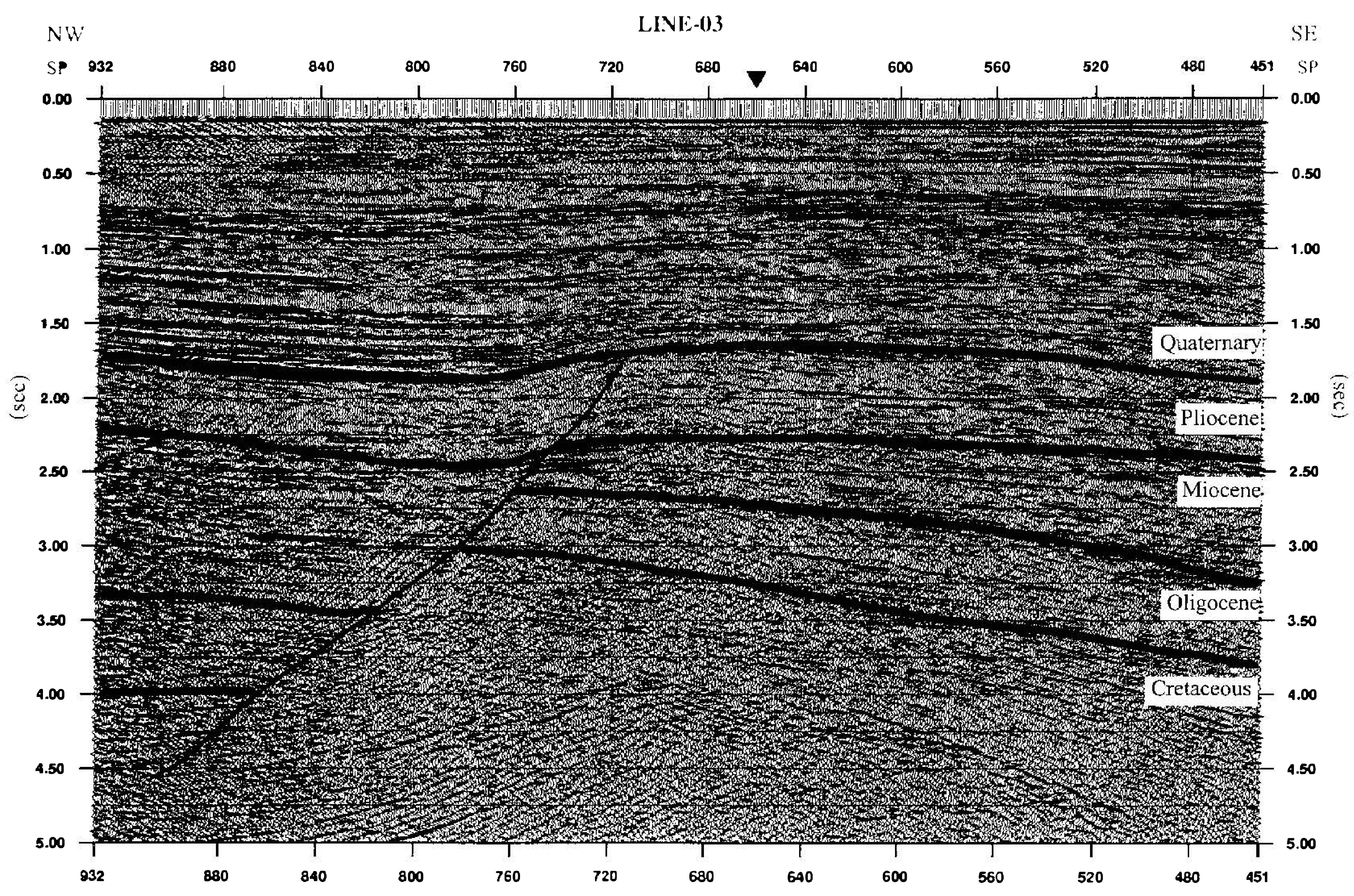

(a)

Line-3 (Ini:ial)
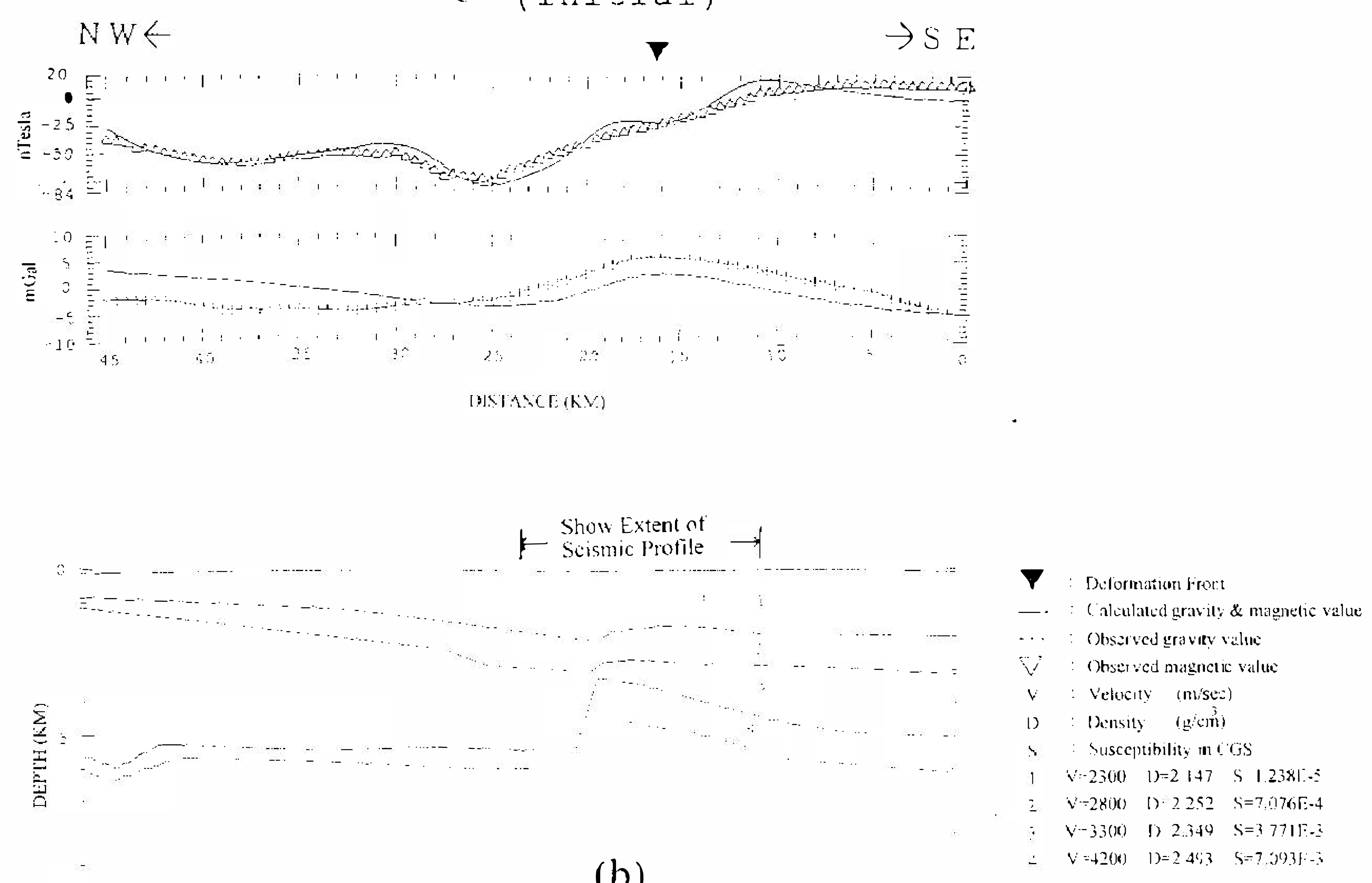

(b)

Fig. 5. (a) Seismic interpretation of Line-3. ( $\boldsymbol{\nabla}$ is the projected location of the "deformation front " along the surface.) (b) Forward modeling based on interpretations of (a) compared with gravity and magnetic data. Note: The seismic profile shown is only part of the length of the modeling profiles. (c) Final structural model compared with gravity and magnetic data after inversion. 

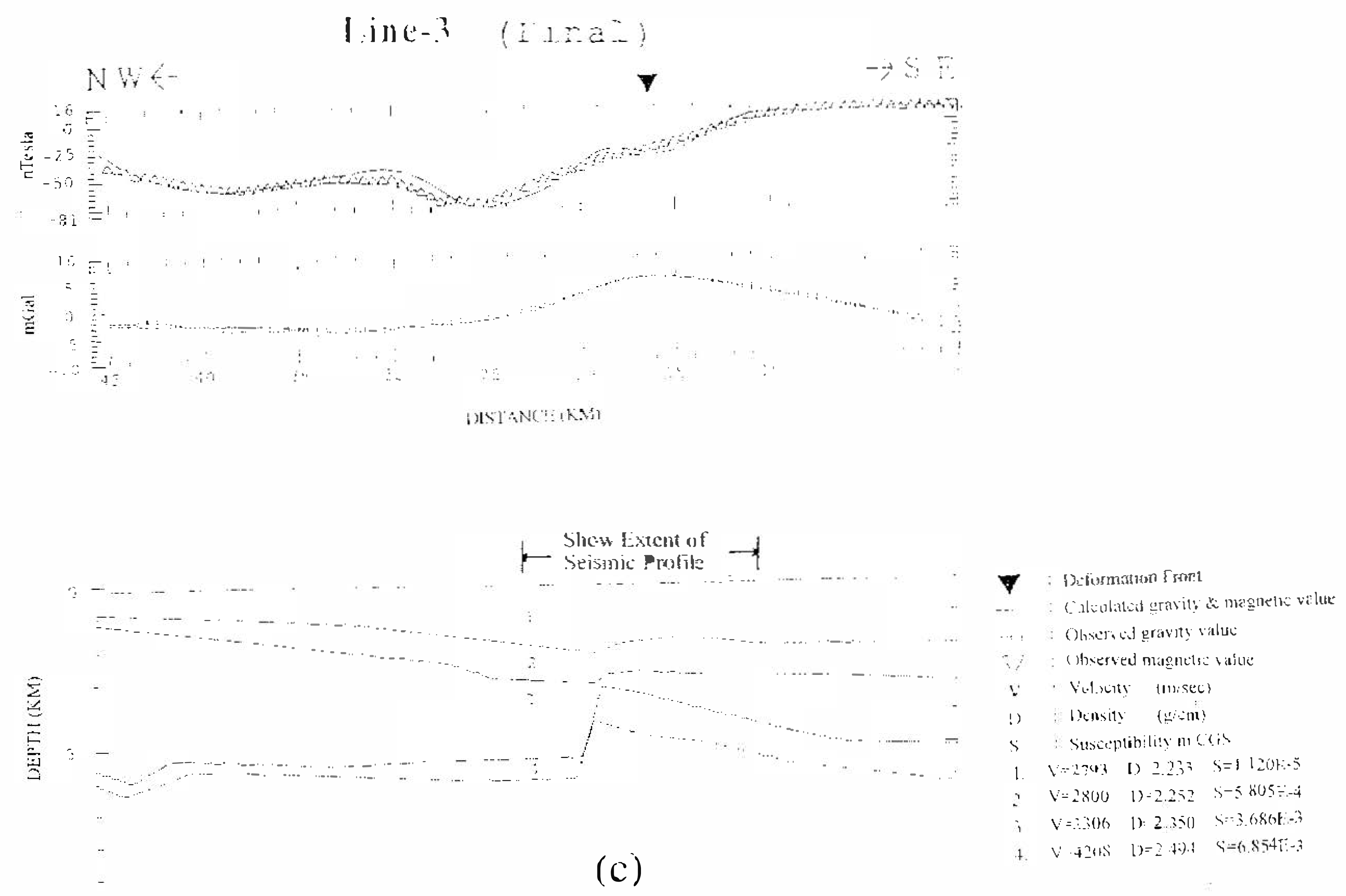

(Fig. 5. Continued.)

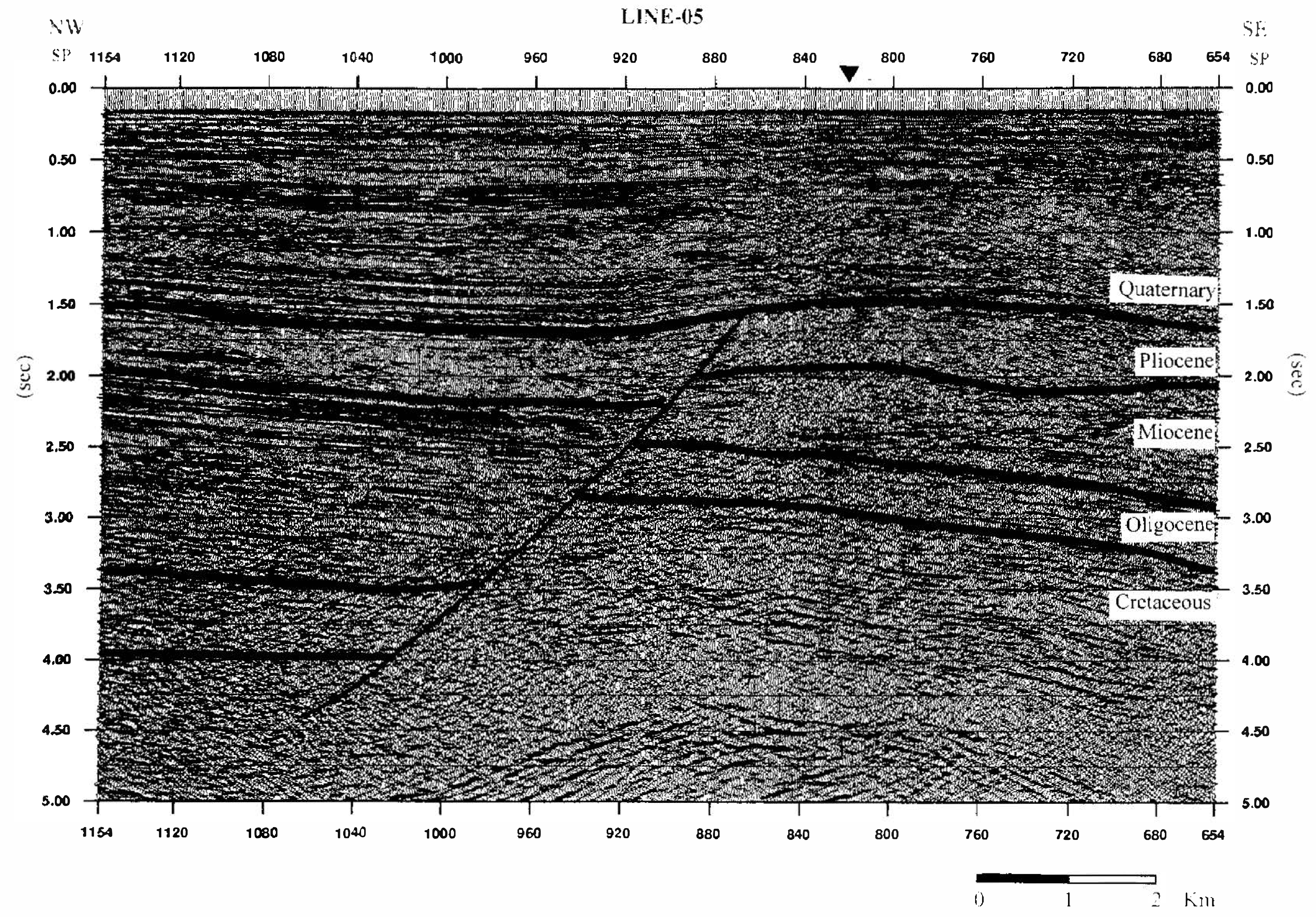

Fig. 6. Seismic interpretation of Line-5. 
Pliocene sediments shallows to 1.4-1.7 sec. The onlap or downlap on the boundary reflections is evidence of the unconformity. Seismic amplitudes vary throughout the section, with medium to poor continuity within the Miocene and Oligocene strata. The thickened strata from the Miocene through the lower Quaternary in the half-graben has been caused by the B Fault.

On Line 7, the "deformation front" is located at shot point 760, where the northwestdipping fault cuts through the unconformity between the Quaternary and Pliocene sediments and causes an offset of at least $100 \mathrm{~ms}$ (Figure 7). The nature of the normal fault is very clear, the hanging wall having moved downward relative to the footwall. The strong reflection at the top of the doming basement deepens further to about $4.5 \mathrm{sec}$ from Line 5 , while the strong reflection from the unconformity between the Quaternary and Pliocene becomes as shallow as $1.2 \mathrm{sec}$.

The proposed "deformation front" is located at shot point 940) along seismic Line-9 (Figure 8). The observed normal fault dips northwest and was active at least until Recent. The acoustic basement has a gentler slope here than in neighboring profiles to the northeast. The top of the basement reaches $4.5 \mathrm{sec}$, and the strong reflections at the basal Quaternary unconformity reverse the rising trend toward the southwest, appearing, in fact, somewhat deeper than on Line 7.

The faulting along the "deformation front" of Line-11 (Figure 9) is of the normal type; the apparent offsets of unconformities along the fault plane decrease from $500 \mathrm{~ms}$ at the top of the Cretaceous to only a slight magnitude for the Quaternary sediments. Apparently, the growth fault was active until Recent. The top of the acoustic basenent is reached at $4.7 \mathrm{sec}$ and continually deepens west ward.

The "deformation front" trends southwestwardly and crosses at shot points 980 and 920 along Line-1.3 and Line-15, respectively' (Figures 10 and 11 ). While the strong reflector at the top of the acoustic basement reaches almost $5 \mathrm{sec}$ in Line-13, it is not clearly observed in Line15. possibly because it is too deep for the 5 -sec records to show. The offset of the strong reflections of unconformity at the top of the Cretaceous maintains about $400 \mathrm{~ms}$ (from $3.2 \mathrm{sec}$ to $3.6 \mathrm{sec}$ ) along the fault plane in both profiles.

The normal fault is no longer observable near the proposed locations of the "deformation front" at shot points 720, 470 and 210 along seismic Lines 17, 19 and 21, respectively (Figures 3 and 12-14). The reflections from the unconformities in these seismic lines have deteriorated and weakened compared to the profiles in the northeast which may have to do wi th the acoustical properties of the sediment deposited in deeper water. No significant offsets due to normal faulting can be positively identified as in profiles to the northeast.

The deeper water and steeper slope of the ocean bottom toward the south in these profiles reflect the shift from the continental shelf to the slope. A trough-like feature more than $1 \mathrm{~km}$ wide is found between shot points 130 and 210 along Line 21.

Both forward and inversed modeling methods of gravity and magnetics were applied to each seismic profile and one typical case is presented here to illustrate how the model was improved to better fit the observed data. The interpreted model based on seismic Line 3 (as shown partly in Figure 5a) yields a general match between the calculated and observed magnetic values in the forward modeling but, on the other hand. the calculated gravity is higher to 


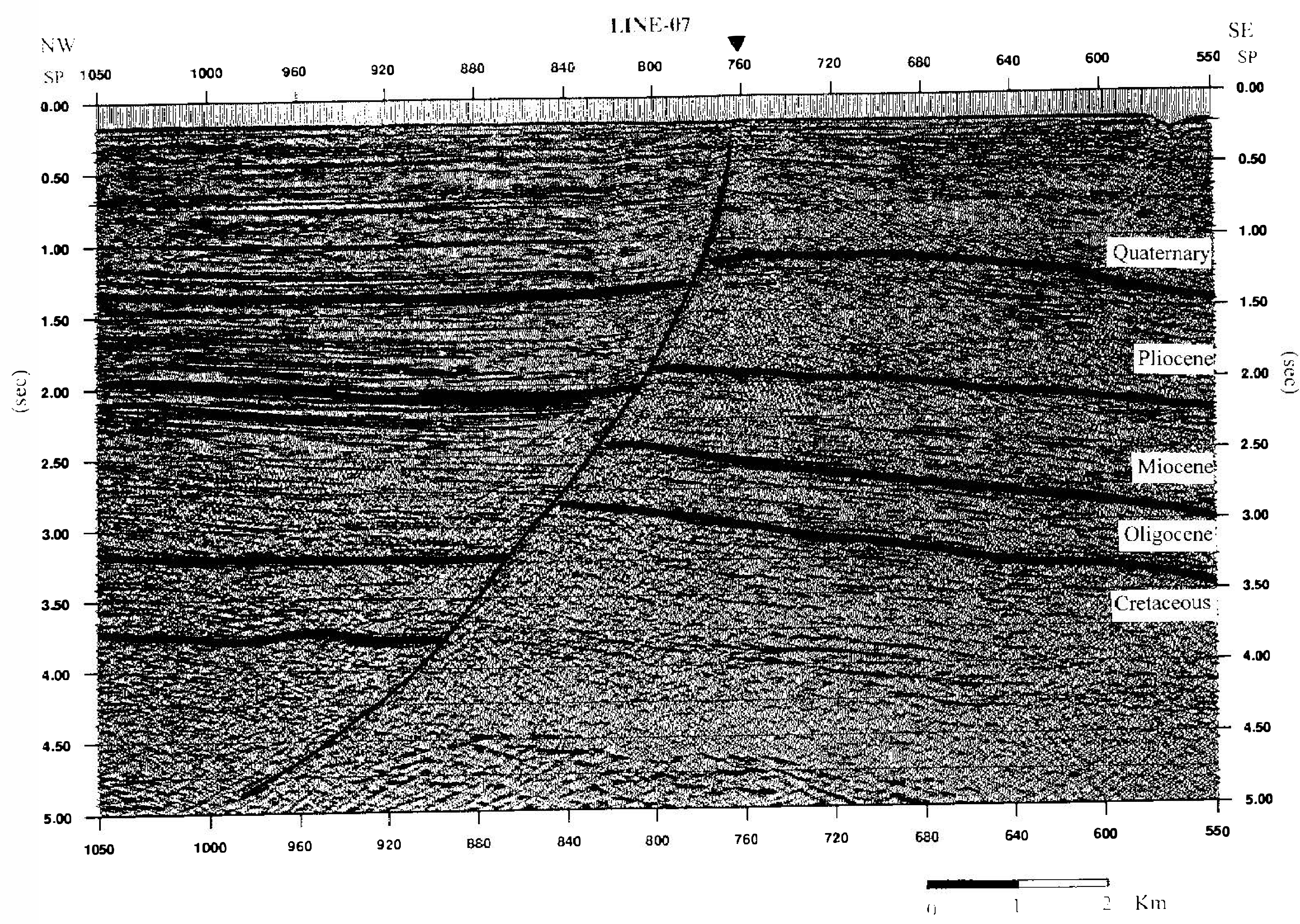

Fig. 7. Seismic interpretation of Line-7.

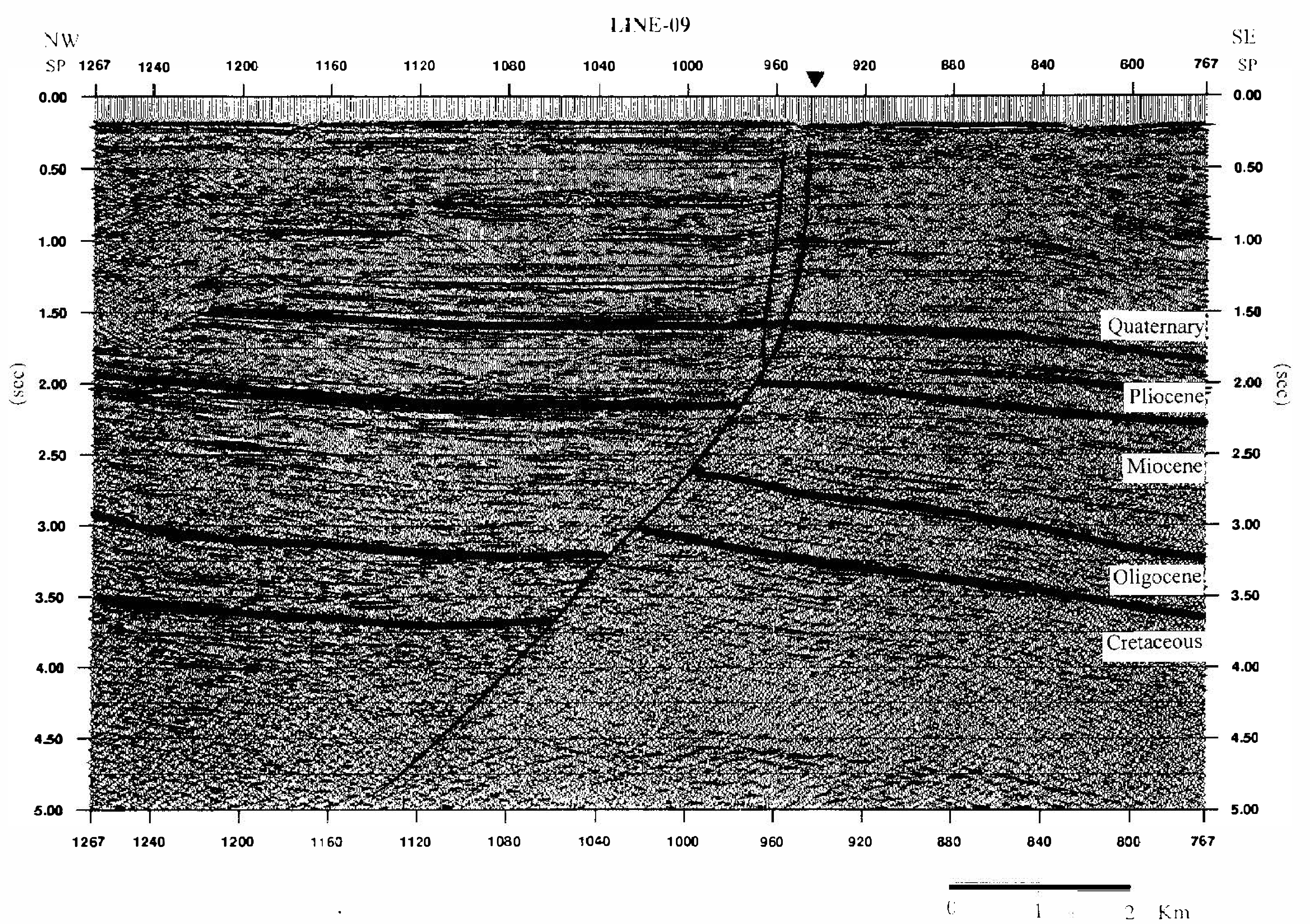

Fis. 8. Seismic interpretation of Line-9. 


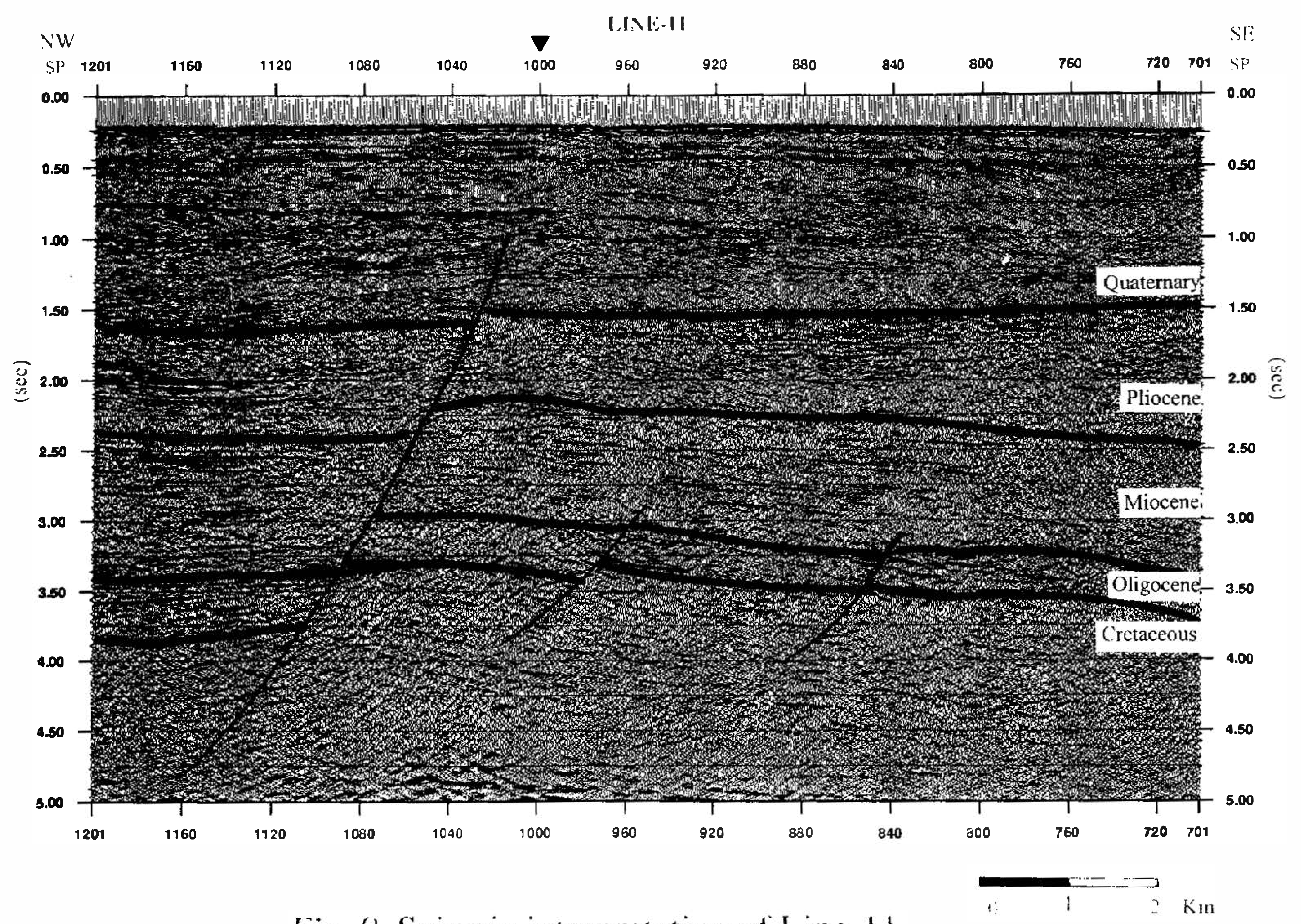

Fig. 9. Seismic interpretation of Line-11.

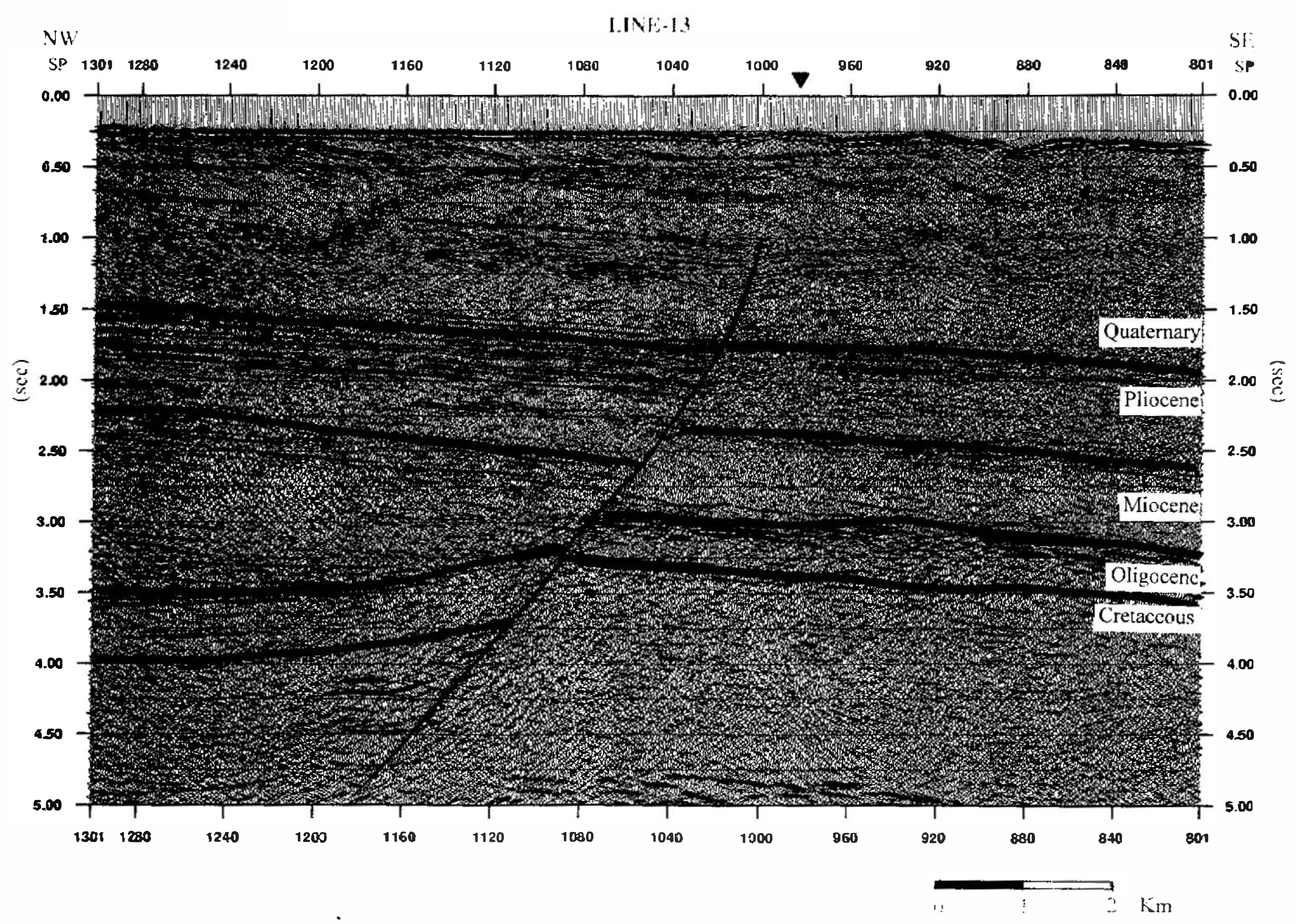

Fig. 10. Seismic interpretation of Line-1.3. 


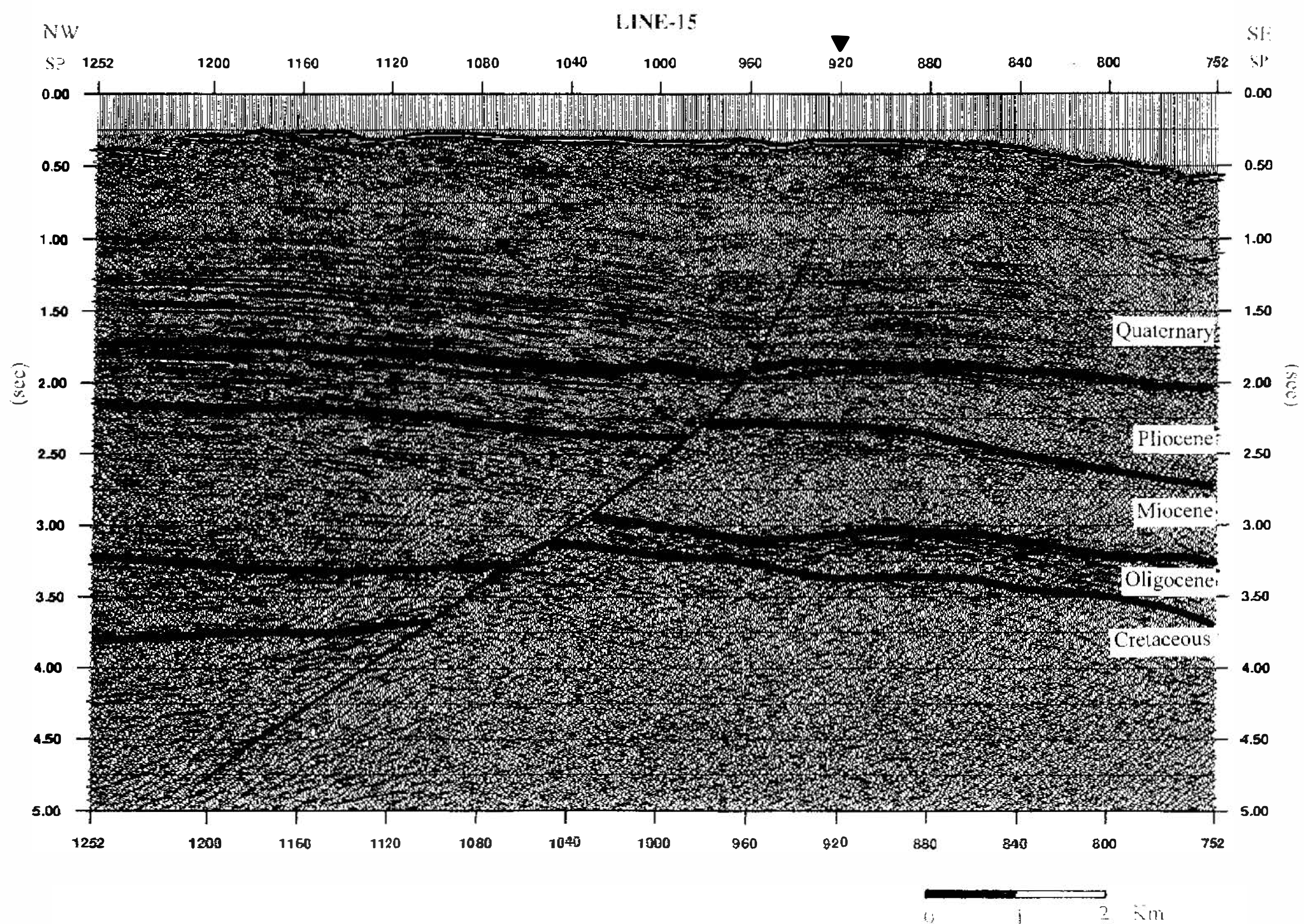

Fig. II. Seismic interpretation of Line-15.

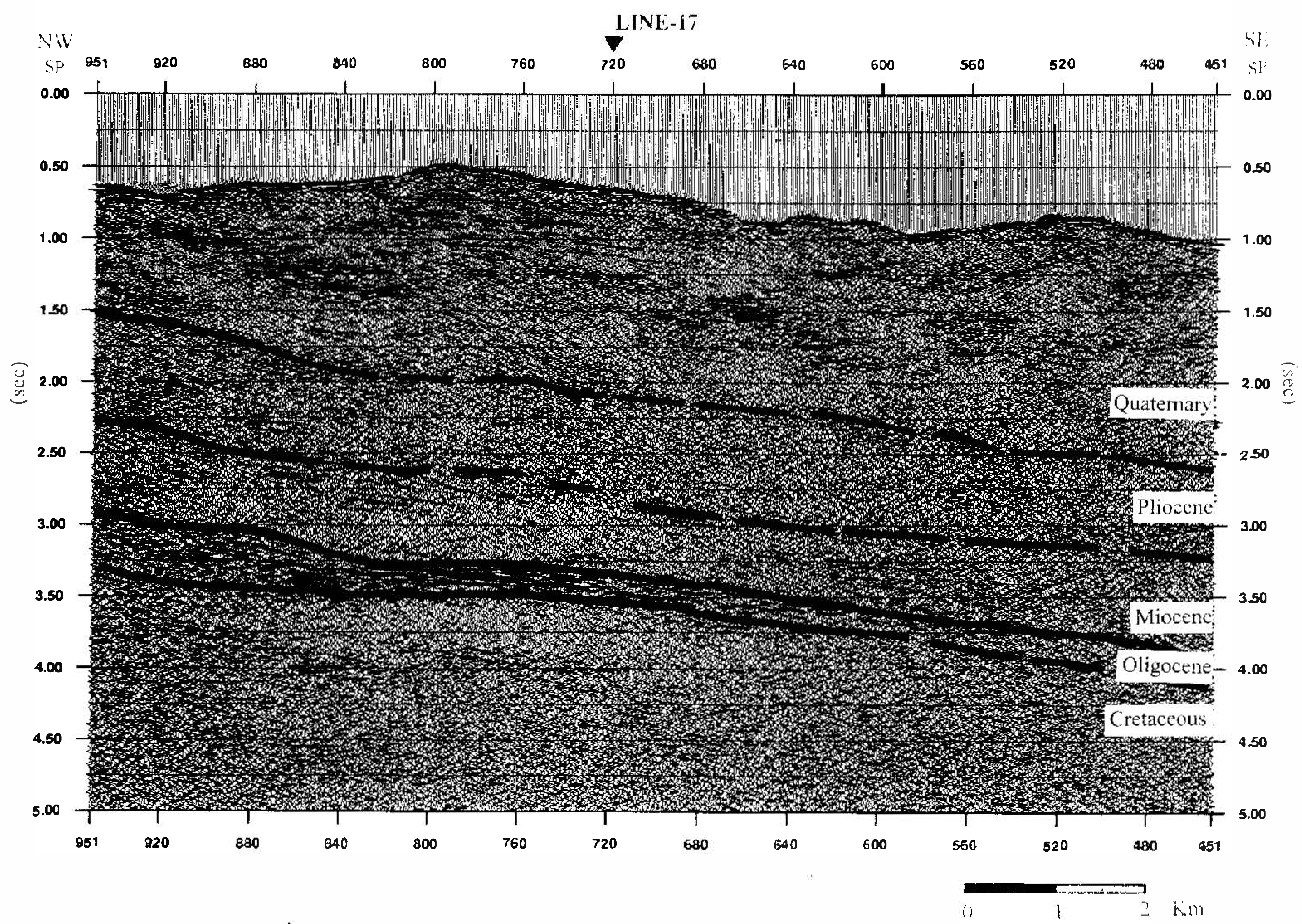

Fig. 12. Seismic interpretation of Line-17. 


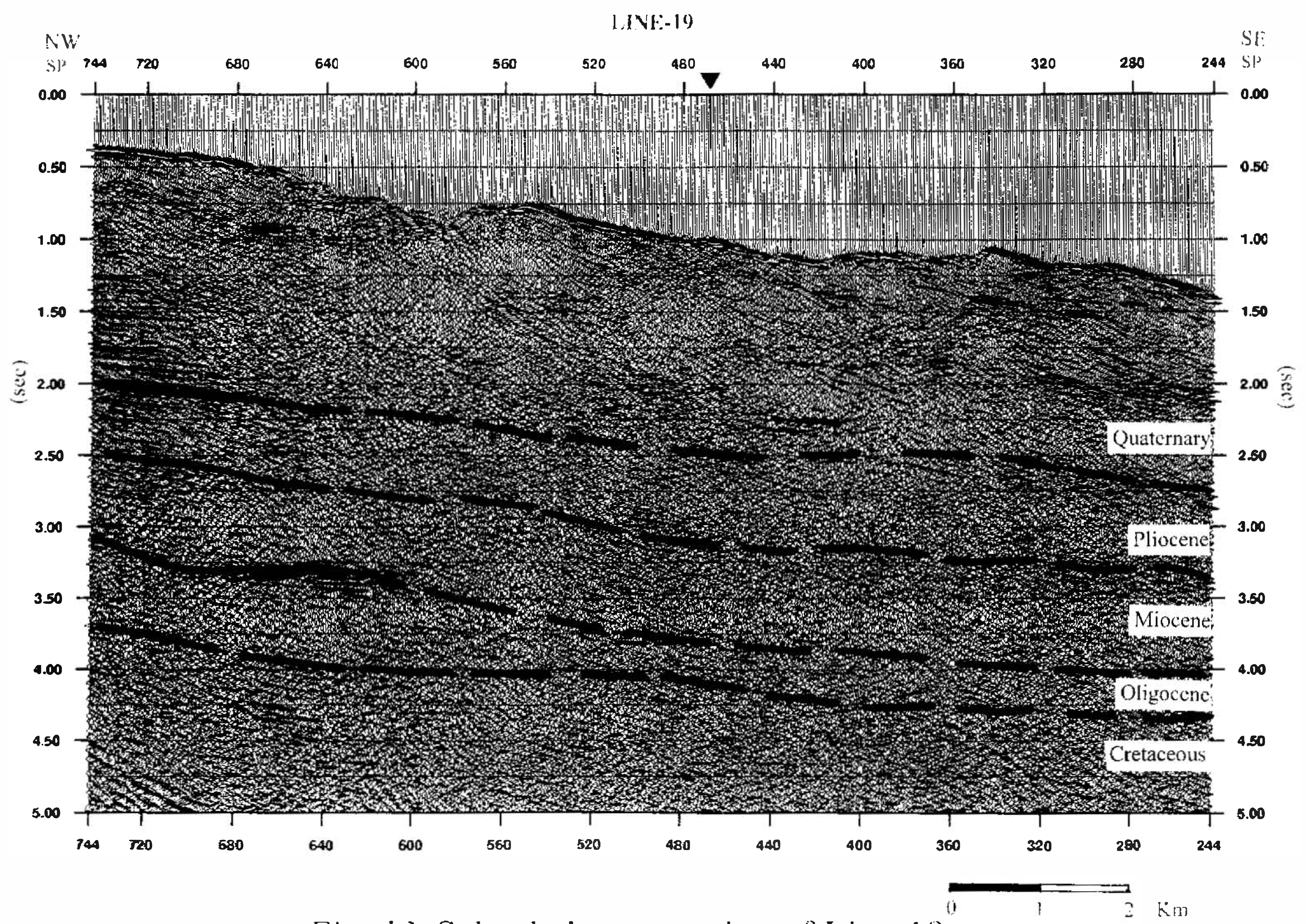

Fig. J.3. Seismic interpretation of Line-19.

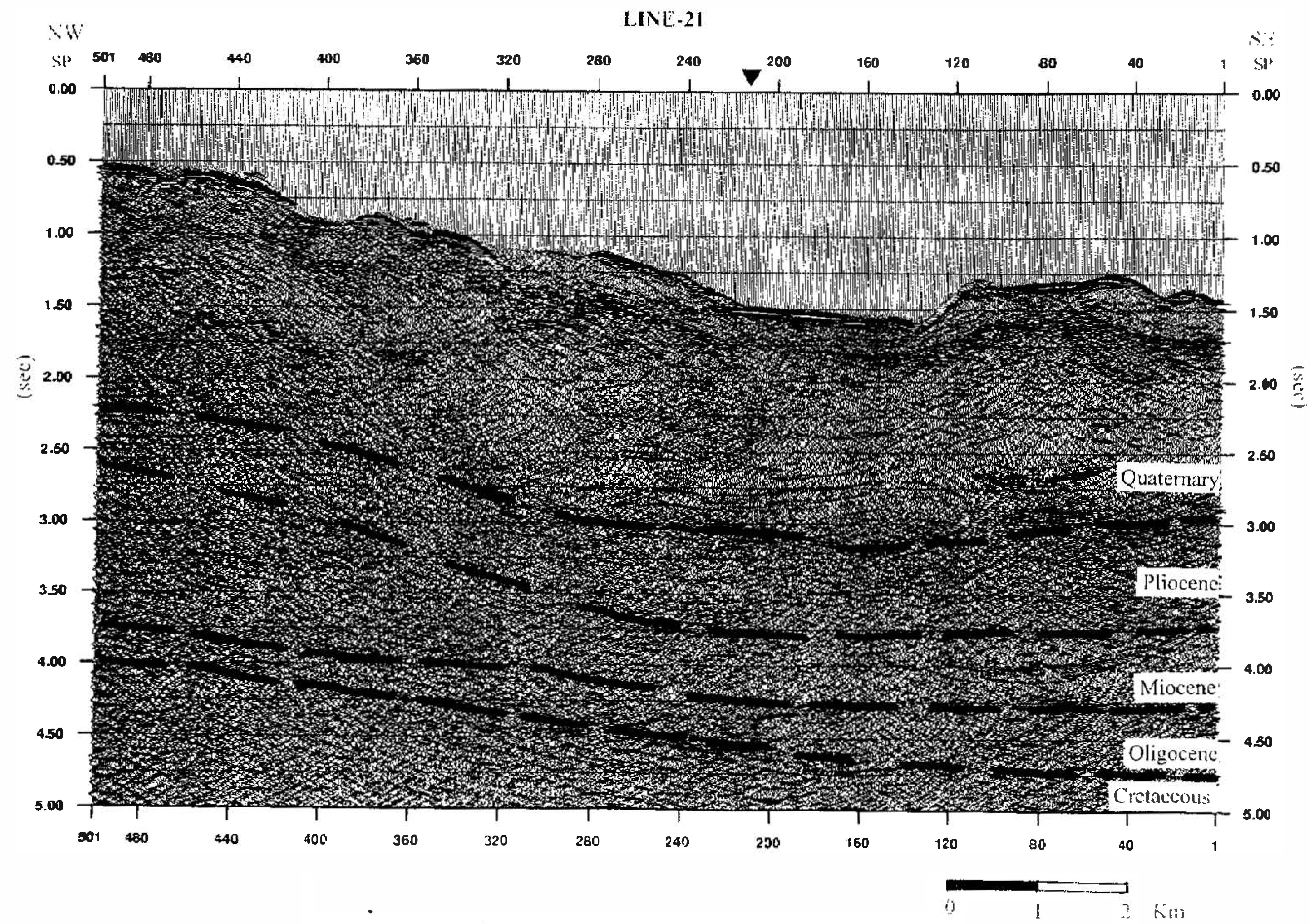

Fig. 14. Seismic interpretation of I Line-21. 
the north and lower to the south than the observed gravity (Figure 5b). Subsequently, the final improved model with an excellent match was obtained after inversion was performed (Figure $5 c$ ), by which the density (from which the velocity could be converted) and susceptibility were slightly revised, and the shape of the initial model is almost unchanged.

The excellent match of both gravity and magnetic data in the present model calculations in forward modeling are also found in all other profiles and supports our seismic interpretations. Slight model adjustments were normally made at the top of either the Oligocene or Cretaceous strata, and accordingly, localized misfits often reflect small, irregular structures within the strata.

\section{DISCUSSION}

The seismic data presented in this study clearly show strong evidence of a major normal fault along the northwestern edge of a structural high, but no evidence of compressional structures. In particular, the "deformation front" caused by collision along the leading edge of the Philippine Sea Plate does not pass through the Tainan Basin. The extension-induced normal faulting occurring since the Cretaceous (Ho, 1982; Ru and Pigotte, 1986; Liang et al.. 1990) may have affected the development of the Tainan Basin until Recent. Gravity and magnetic modeling confirm the existence of normal fault dipping to the northwest. The normal fault might be the NE extension of the B Fault, which separates the Central Uplift from the North Recession (Figure 15).

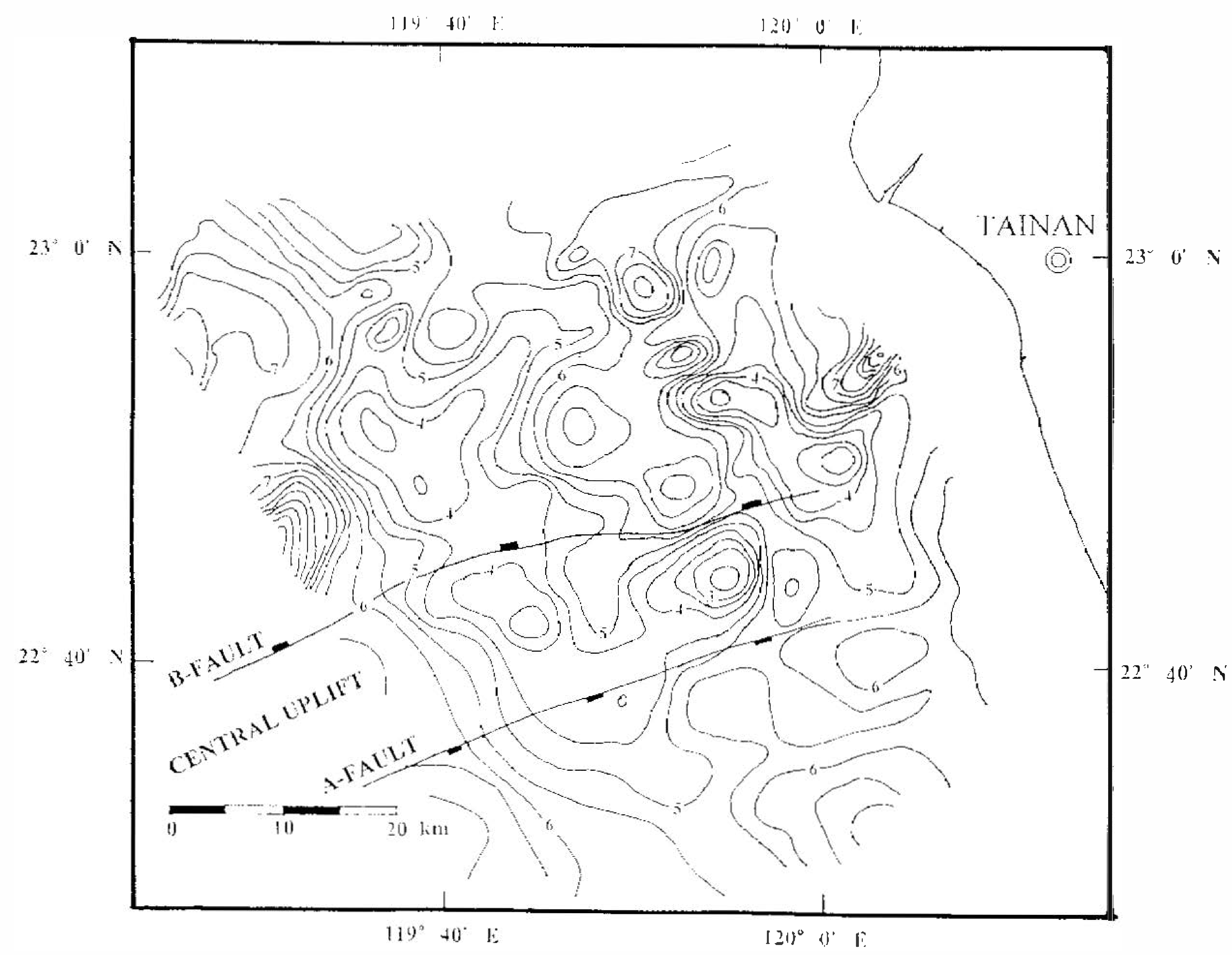

Fig. 15. Depth structure map of the economic basement at the top of Pre-Tertiary rock based on the finalized model of potential-field and seismic reflection data in this study. Contours are depth beneath sea level in kilometers. 
The values of susceptibility, velocity and density adopted in each layer in modeling vary from line to line and may reflect lithologic inhomogenieties due to contrasting depositional environments. As for seismic velocity, it is found that the overall range of interval velocities is comparable among the data based on sonic logs and those derived from stacking velocities, while the averaged model velocities of each layer converted from density on the basis of gravity inversion are somewhat higher (Table 2). Furthermore, velocity analyses during processing show that velocities tend to increase laterally toward the southeast. such a trend of increasing velocity implies that either the compaction or the age of the sedimentary rock increases in the same direction.

Although gravity and magnetic modeling provide an opportunity to confirm the seismic interpretations from this study, the authors are well aware of the non-uniqueness of inversion solutions. The oversimplified model with single values of average velocity and density assigned to each layer along with the uncertainty of local variations in topography can all lead to some degree of inaccuracy. Yet the initial values of susceptibility assigned to each layer were revised and gradually converged to the final results after reiterating inversion. The trend of variation in susceptibilities shows that values increase downward, although there are local differences throughout the region.

A structural map of the economic basement (i.e., the depth to the top of the pre-Tertiary rock) was generated based on finalized models of potential-field data (Figure 15). The structural high that coincides with the Central Uplift maintains a depth from 3 to $5 \mathrm{~km}$ and deepens to more than $5 \mathrm{~km}$ in either direction away from the uplift zone.

To further demonstrate the characteristics of normal fault bounding the Central Uplift zone, seismic Line-5 (Figure 16) was compressed to less than one-fifth of its length. The vertically exaggerated profile show's a salt dome-like feature, with fault that could clearly be interpreted as normal.

Since, on the basis of our geophysical investigation, the compressional stress related deformation front was not found in the Tainan Basin, it should be located somewhere further to the south. One such possibility (Lee et cl., 1993), which was based on seismic interpretation, suggested that it is located near Kaohsiung.

The important episode of arc-continent collision has caused the rapid uplift of the Central Range of Taiwan which has consequently become the main source of sediments transported and deposited in the Tainan Basin since the Pliocene. Although it has not affected the extensional nature of the structures developed in the Tainan Basin as shown above, the collision has hindered any further development of the basin.

Table 2. P-wave velocity $(\mathrm{m} / \mathrm{sec})$ in different layers.

\begin{tabular}{lcll}
\hline Sequence & Sonic Logs (well data) & Interval Velocity & Model Velocity' \\
Quaternary & $1607-2646$ & $1617-2874$ & $2079-2709$ \\
Pliocene & $2418-3042$ & $2475-3294$ & $2767-3086$ \\
Miocene & $2774-3787$ & $2755-3676$ & $3012-3983$ \\
Oligocene & $3493-4578$ & $3417-4362$ & $4081-4535$ \\
Cretaceous & $3600-4962$ & & \\
\hline
\end{tabular}




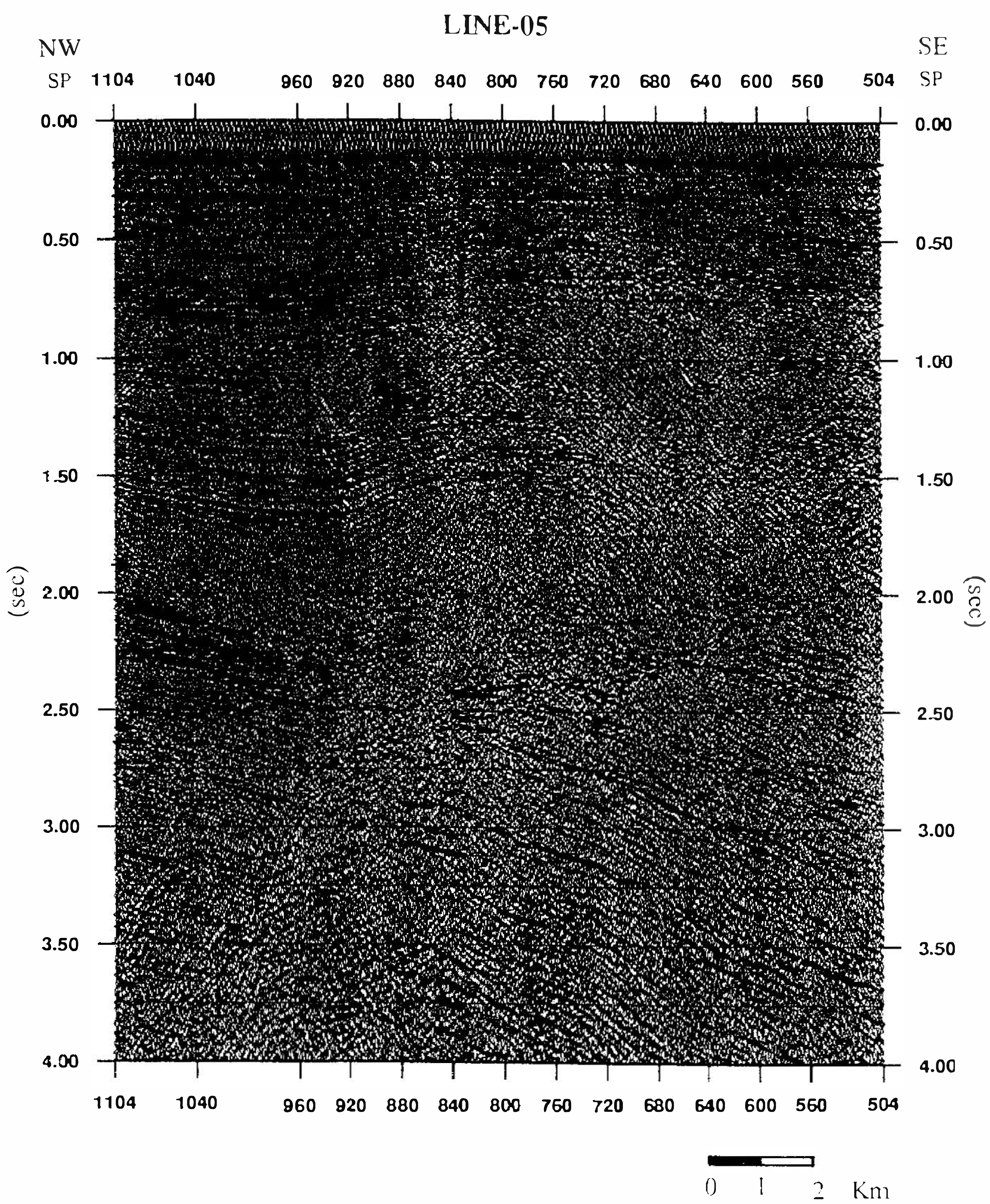

Fig. 16. Vertically exaggerated plot of Line-5.

\section{CONCLUSIONS}

Studies on the nature of faulting based on seismic, gravity and magnetic data described above confirm that normal faults striking northeast have been related to extensional stress since the initiation and development of the Tainan Basin in the Latc Oligocene. The deformation front of the arc-continent collision must be located southeastward of this basin. Therefore, it can be concluded that the plate boundary between the Eurasian and Philippine Sea Plates does not pass through the basin.

It is further concluded that the depth to the top of the pre-Tertiary, which is defined as the top of the economic basement, ranges from 3 to $5 \mathrm{~km}$ in the Central Uplift and is deeper in both the North and the South Recession. The thick Tertiary sediments deposited in the Tainan 
Basin could provide favorable conditions for oil generation and sealing. The normal faulting offers the opportunity of forming structural highs for oil migration and accumulation. Petroleum exploration should be thus directed in searching for prospects related to the normal faults.

Acknowledgments The authors wish to thank the Chinese Petroleum Corporation for providing the data and processing facilities used in this study. Thanks are also due to Tsao-Chang Hu, Yuan-Wei Lee, Pi-Hsia Hsu and Mei-Jong Sun for their useful information and technical help.

\section{REFERENCES}

Biq, C. C., 1972: Dual-trench structure in the Taiwan-Luzon region. Proc. Geol. Soc. Chinct, $15,65-75$.

Biq, C. C., 1973: Kinematic pattern of Taiwan as an example of actual continent-arc collision. Rep. in the Seminar on Seismology, US-ROC Cooperative Sci. Prog., 21-26.

Bowin, C., R. S. Lu, C. S. Lee, and H. Schouten, 1978: Plate convergence and accretion in Taiwan-Luzon region. Am. Assoc. Petrol. Geol. Bull., 62, 1645-1672.

Chen, A. T., and W. R. Ho, 1992: Problem of the existence of Manila Trench off southwestern Taiwan. The Fourth Taiwan Symposium on Geophysics, Keelung. Taiwan, 487-491.

Chuang, K. C., T. F. Chou, S. T. Tsai, and C. J. Lee. 1991: Reservoir and paleoenvironment study of the northern Tainan Basin. Exploration and Development Res. Center Rep., Chinese Petroleum Corporation, 14. 22-34.

Gardner, G. H. F., L. W. Gardner; and A. F. Gregory, 1974: Formation velocity and densitythe diagnostic basics for stratigraphic traps. Geophysics, 39, 770-780.

Hayes, D. E., and S. D. Lewis, 1984: A geophysical study of the Manila Trench, Luzon. Philippines crustal structure, gravity, and regional tectonic evolution. J. Geophlys. Res.. 89, 9171-9195.

Ho, C. S., 1982: Tectonic evolution of Taiwan: Explanatory text for the tectonic map of Taiwan, Ministry of Economic Affairs. Taipei, 126pp.

Hu, C. C., 1988: Basement structure and the Oligocene to Miocene stratigraphy of the Tainan Basin. Petroleum Quarterly, 23, 104-115 (in Chinese).

Huang, Y.L., 1993: Structural styles of ffshore southwestern Taiwan. M. S. thesis, Department of Geology, National Taiwan University (in Chinese), 58pp.

Karig, D. K., 1973: Plate convergence between the Philippine and the Ryukyu Islands. Mar. Geol., 14, 153-168.

Lee, T. Y., C. H. Tang, J. S. Ting, and Y. Y. Hsu, 1993: Sequence stratigraphy of the Tainan Basin, offshore southwestern Taiwan. Petrol. Geol. Taiwan. 28, 119-158.

Letouzey, J., and L. Sage. 1988: Geological and structural map of Eastern Asia. Am. Asso. Petrol. Geol., Tulsa, Oklahoma.

Liang, D., and Z. Liu, 1990: The genesis of the South China Seal and its hydrocarbon-bearing basin. J. Petrol. Geol., 13, 59-70.

Lin, M. T., and Y. B. Tsai, 1981: Seismotectonics in the Taiwan-Luzon area. Bull. Inst. Earth Sci., Academia Sinica, 1, 51-82. 
Lundberg, N., D. L. Reed, and C. S. Liu, 1991: The submarine propagation tip of the Taiwan collision: shallow crustal structure and orogenic sedimentation. Taicrust Workshop Proceedings, Taipei, Taiwan, 93-102.

Page, B. M., and J. Suppe, 1981: The Pliocene Lichi melange of Taiwan: its plate tectonic and olistostromal origin. Am. J. Sci., 281, 193-327.

Pan, Y.S., 1968: Interpretation and seismic coordination of the Bouguer gravity anomalies obtained in southern Taiwan. Petrol. Geol. Taiwan, 6, 197-207.

Pelletier, B. and J. F. Stephan, 1986: Middle Miocene obduction and late Miocene beginning of collision registered in the Hengchun Peninsula. Geodynamic implications for the evolution of Taiwan: Tectonophysics, 125, 133-160.

Ru, K., and J. D. Pigotte, 1986: Episodic rifting and subsidence in the South China Sea. Am. Asso. Petrol. Geol. Bull., 70, 1136-1155.

Suppe, J., 1988: Tectonics of arc-continent collision on both sides of the South China Sea, Taiwan and Mindoro. Acta Geol. Taiwanica, 26, 1-18.

Telford, W. M., L. P. Gedart, R. E. Sheriff, and D. A. Key, 1976: Applied geophysics. Cambridge, England, Cambridge University Press, 860pp.

Teng, L. S., 1990: Late Cenozoic arc-continent collision in Taiwan. Tectonophysics, 183, 5776.

Tsao, C. Q. and M. Chang, 1988: Study of petroleum potential in Oligocene sandstone of Tainan Basin. Mining and Metallurgy, 33, 49-57 (in Chinese). 